\title{
Applying geoethics to the context of mining ferruginous geosys- tems: case studies from the tailing dam breaks in Fundão and Córrego do Feijão, Minas Gerais - Brazil
}

\author{
${ }^{1}$ Federal University of Minas Gerais - Institute of Geosciences, Av. Pres. Antônio Carlos, 6627 - Pampulha, Belo Horizonte - MG, $31270-901$ \\ - Brazil; *Corresponding author, E-mail: tularuchkys@yahoo.com.br \\ ${ }^{2}$ Federal University of Ouro Preto - Department of Geology, Campos Morro Do Cruzeiro, s/n - Bauxita, Ouro Preto - MG, 35400-000 - Brazil
}

(Received: April 11, 2019; Revised accepted: April 16, 2020)

https://doi.org/10.18814/epiiugs/2020/020060

Geoethics is an emerging concept particularly suited to planning and managing the use of geo-resources (including water and soil). The main objective of this paper is to explore geoethics to contextualize the problems associated with mining activities in ferruginous geosystems, using as examples the ruptures of the Fundão and the Córrego do Feijão dams, both located in the Quadrilátero Ferrifero $(Q F)$, in the state of Minas Gerais - Brazil. Mining industry in the region has been developing for centuries being a guiding thread of the identity and memory of the local communities. By claiming to bring economic returns to the area, mining has been transforming the environmental balance and the physiognomy of landscapes. By examining the context of the rupture of two dam breaks (human and environmental losses), our work challenges the prevailing view that mining, as practiced in the QF, only brings development and aggregates value to the population. Instead, our work highlights that the performance of mining sector as a whole, and the mining companies in particular, requires a more responsible and ethical action towards society. We therefore call for the need to include geoethical approaches in mainstream landscape management strategies in ferruginous geosystems in Brazil.

\section{Introduction}

Mineral resources, from the birth of the first hominids to the present time, have always been object of attention. The exploitation of mineral resources is often associated to the improvement of the quality of life extending well beyond the areas where mineral resources are extracted. Velho (2006) enumerates five historical moments defined by him as "geossocials" in which people's livelihoods were completely changed by the use of the geological heritage: metal (Age of copper, bronze and iron used as material); gold (as money); coal (as energy); oil (as energy); radioactive minerals (such as energy). The five moments identified above show an increasing trend in the consumption of mineral resources accompanied by demographic growth all leading to increasing pressures on the natural environment (Velho, 2006).

In this context, the concept of sustainability makes room for a set of newer approaches to geosciences, amongst them, the geoethical approaches. Geoethics deals with ethics related to the social, economic, environmental, and cultural aspects of research and practice in geology. Geoethics provide an intersection point between geosciences, sociology and philosophy (Peppoloni and Di Capua, 2012; Peppoloni, 2012; Bohle and Di Capua, 2019).

Goals of geoethics include but are not exclusive to: sustainable development in the use of geological resources; the proper management of its natural risks; communication across geological science and caring for its legal aspects; museology, and finally; the unconditional care for our planet and our heritage (Druguet et al., 2013). In line with the concept of geoethics is the definition of responsible mining that was proposed by the Working Group on Responsible Mining of the International Association for the Promotion of Geoethics (IAPG) in 2017. Responsible mining was defined as a mineral extraction activity that respects all stakeholders, business, state and society, protecting the interests of all of them, and consequently promoting human health and the environment. It also focuses on contributing to the country's economic development, benefiting local communities, using Best Available Techniques (BAT) and acting under the rule of law (Arvanitidis et al., 2017). Other international organizations, such as the International Council on Mining and Metals (ICMM), have as principle the promotion of sustainable, socially and environmentally safe mineral industries, valuing commitments to the communities and countries where their signatory companies are installed. In the case of Brazil, a country recognized for its mineral wealth (Ribeiro Filho et al., 1988), not only the development of geoethical principles, but prominently their adoption into mining practices (and associated incorporation into the mining companies' attitude) needs to be encouraged and supported in order to become mainstream.

In this context, the main objective of this paper is to include geoeth- 
ics to contextualize and analyze the problems associated with mining activities in ferruginous geosystems, using as examples the ruptures of the Fundão and the Córrego do Feijão dams, both located in the Quadrilátero Ferrífero (QF), in the state of Minas Gerais - Brazil.

The structure of the paper is as follows: after this Introduction we will explore the problem under study addressing the context of Ferruginous Geosystems and mining. We then present our results starting by setting the international context of the rupture of mining tailings dams of Fundão and Córrego do Feijão. We then describe the losses involved (both social and natural) in the two case studies (Fundão and Córrego do Feijão). Following this, we discuss ways forward in order to apply geoethics into the context of dam ruptures. Finally, we summarize key findings and explore ways forward.

\section{Ferruginous Geosystems and Mining}

Ferruginous geosystem (Carmo and Kamino, 2015) are areas containing deposits of iron ores. These deposits comprise a set of iron ore formations that, in general, include itabirite, jaspilite, among other rocks with a concentration of precipitated iron either chemically or biochemically (Ruchkys, 2015).

Minas Gerais State has one of the most significant ferruginous geosystems in the world known as the Quadrilátero Ferrifero (QF). Its history is related to the mining activities that began with the Gold Cycle in the seventeenth century and went through the 19th century focusing on the exploitation of iron ore. QF is one of the most important ferruginous geosystems in Brazil. In addition to being an important mineral province, this region is also known as the nursery for the development of the Minas Gerais population holding important heritage values from geological, historical, cultural and biological points of view, among others (Ruchkys, 2015).

The USGS (2014) estimates iron ore production in Brazil as 398 million tons in 2013, equivalent to $13.5 \%$ of the production worldwide. In 2015, most mineral commodities showed falling prices (DNPM, 2015a), likely associated to a diverse number of facts such as (i) the transition of China's economic model, from a commodity-intensive economy to a service and consumption-driven economy, (ii) a weak demand from emerging markets, and (iii) a global excess of mineral supplies-DNPM, 2015a). Despite consecutive decreases in the Brazilian industrial production (of 8.3 and $9.1 \%$, from January to December 2015 and from January to June 2016, compared to the same periods of 2014 and 2015, (DNPM 2015b, 2016), industrial activities related to mineral extraction showed an increase of $3.9 \%$ in 2015 (motivated mainly by an expansion in the production of some items, such as crude oil and iron ore, DNPM, 2015b). On the other hand, between the months of January and June of 2016, the Brazilian mineral extraction industry, largely influenced by a reduction in the production of iron ore, decreased 14\% (DNPM, 2016; Pinheiro, 2018).

Despite these fluctuating global scenarios, Brazil is one of the worldwide producers of iron ore and a high share of its production occurs in the region of Quadrilátero Ferrífero $(\mathrm{QF})$. Mining activities and the economic interests on the exploration of the QF ferruginous geosystem in Minas Gerais are part of the identity of the region and embedded into the culture of its inhabitants. It is precisely because mining is part of the cultural identity of Minas Gerais that makes the integration between mining activity and nature protection, despite highly complex, absolutely essential. Geoethics is therefore an important tool in order to reconcile mining activities with respect for the abiotic environment and need to search for a more responsible and fraternal society. Geoethics is useful for both mining industries and geoscience professionals that are seeking to mitigate environmental problems and reduce the side effects of mining practices that damage the environment and threaten human well being.

\section{Results}

\section{Setting the International Context of the Rupture of Min- ing Tailings Dams of Fundão and Córrego do Feijão}

Tailings are the output material (residues) of iron ore processing. The disposal of tailings is made in containment structures normally built in basins or valleys. The process starts by raising a dam that should have tailings retention capacity for two or three years of mining activity. As mining activities proceed the dam height grows higher (operation known as alteamento in Portuguese). These embankments can be constructed using the tailing material itself using one the following methods: upstream, downstream or centerline (Cardozo et al., 2016). Other forms of disposal are underground pit deposition in controlled piles. For mining companies the variables considered to determine the best option to deal with tailings are usually limited to the economic ones, since tailing deposition is a no return investment (EPA, 1994; Lozano, 2006).

The emphasis on maintaining or expanding mineral extraction profits, to the detriment of consideration of environmental and social variables, is not, however, compatible with ethical guidelines, as stated in the 1988 Constitution of the Federative Republic of Brazil (CFRB). According to the constitutional text (article 170, VI), environmental protection - including geodiversity, biodiversity, waters and social groups - must be seen as a principle of the economic development (Brasil, 1988; Derani, 1998, 2008). Therefore, the protection of the environment must guide the way in which the extraction and exploitation of natural resources occur. It is important to clarify that the legal responsibility for damage or environmental disasters in Brazil is "objective", according to Federal Law No. 6938 of 1981 on the national environmental policy. Thus, the companies Vale, Samarco and BHP Billiton are legally responsible for the mining disaster in Mariana (Fundão), and the company Vale is legally responsible for the mining disaster in Brumadinho (Córrego do Feijão), because they are, in fact, owners and managers of the tailings dams that collapsed. In Brazil, the definition of environmental legal responsibility is said to be "objective" because this definition does not require investigations into aspects of the guilt of a person, a company or its individually considered members (Drummond and Barros-Platiau, 2006; Leite and Ayala, 2020).

However, most mining corporations in Brazil interpret the need for investments in the protection of natural and cultural heritage as reducing profitability and as impairing the full exercise of the right to mining. Historically, research has shown that companies are resistant to limiting mineral exploration and in adopting the best mining technologies (often more expensive) available in order to protect the environment (Gutberlet, 1996; Hochstetler, 1997; Hochstetler, 2002; Araujo, 


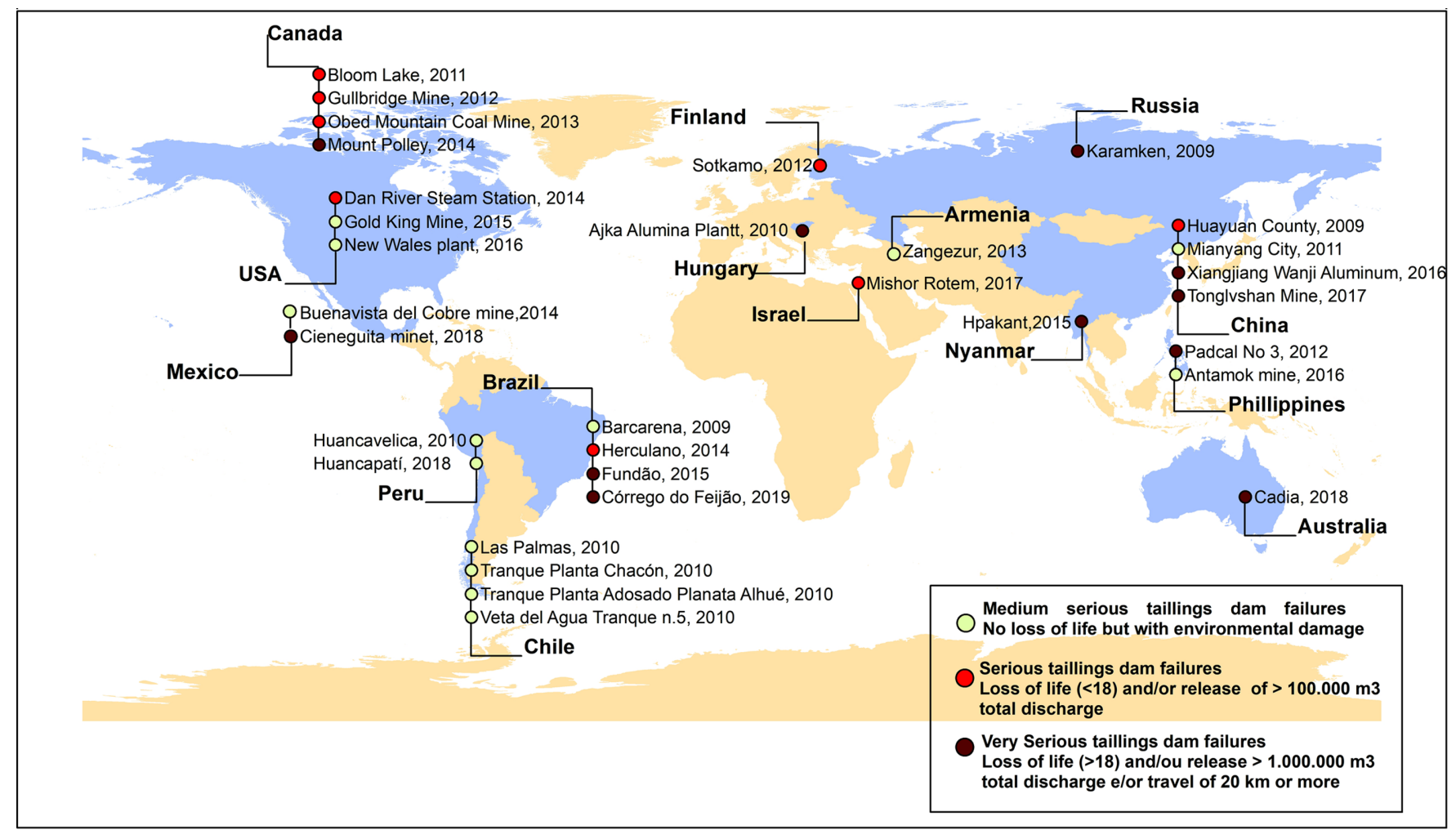

Figure 1. Larger tailing dam rupture events between 2009 and 2019. Source: Data from Wise Uranium Project, 2019. Based on the United Nations Environment Program and GRID-Arendal, Nairobi and Arendal Mine 2017.

Olivieri and Fernandes, 2014; Alvarenga, 2015).

According to Brazilian law (CFRB, article 170, VI; Federal Law No. 6938, article 4, I and VI) the public agencies responsible for environmental management and supervision must require companies, namely mineral extraction companies, to implement ecologically sustainable production standards. However, these public agencies have been showing difficulties in assessing the environmental risks and damages caused by mining companies, especially in territories such as Minas Gerais, historically associated with mining (Alvarenga, 2015; Santos and Borges, 2019).

Tailing dam ruptures may occur for a number of reasons, including: piping, liquefaction, flooding and deposition rates greater than tailing dam capacity, amongst others. The cost of tailing dam breeches is high because it involves environmental and social losses.

Although catastrophic events have occurred around the world, Bower and Cambers (2017) point out that Mt Polley in Canada (2014) and Fundão in Brazil (2015) have brought the urgent need for a global review of the mainstream assumption that impacts are unavoidable and offset by a greater demand by society and the public benefits originated by mining. Figure 1 shows the largest tailing dam rupture events in the last ten years (2009 to 2019).

The two tailing dam breaks in Brazil namely the Fundão (2015) and Córrego do Feijão (2019), were both ranked in the highest class concerning the damages caused. As far as environmental damage is concerned, the disruptions that led to the largest discharge of tailings in terms of volume $\left(\mathrm{m}^{3}\right)$ were: Fundão / Brazil $(43,000,000)$; Mount Polley / Canada $(23,600,000)$; Padcal No 3 / Philippines $(13,000,000)$ and Córrego do Feijão / Brazil $(12,000,000)$. On the other hand, considering the number of deaths and human losses the (accounting for identified and disappeared), the greatest damages were caused in: Córrego do Feijão / Brazil (257); Hpakant / Nyanmar (113); Fundão / Brazil (19) and Cienegyuta minet / Mexico (7). The two Brazilian tailing dam ruptures: Fundão (explored by Samarco-Vale- BHP Biliton) and Córrego do Feijão (operated by Vale) were the largest in the world in terms of both environmental damage and the number of human losses.

Millions of tons of tailings are deposited every year in tailing dams of the Quadrilátero Ferrífero. This region is cumulatively the region of Minas Gerais state with higher urban concentration. In the year 2014, 15 large mines of different companies produced 273.1 million tons of ore, which generated 111.6 million tons of tailings (DNPM cited by Gomes, 2017). Figure 2 shows the classification of some tailing dams in the region in relation to their potential damage according to the State Foundation for the Environment (FEAM), which creates and monitors the environmental system of the State of Minas Gerais.

For classifying the tailings dams according to specific legislation (FEAM Normative Deliberation No. 62, September 17, 2002) FEAM uses data of the size of the tailing dam and the reservoir, classifying them as small, medium and large according to five criteria: height of the massif; human occupation downstream of the tailing dam; environmental interest in the area downstream of the tailing dam; presence of facilities in the area downstream of the tailing dam. Using the parameters listed above, the tailing dams are classified into three categories, considering the sum of the values assigned to each parameter: class I (low potential of environmental damage); class II (average potential of environmental damage); class III (high potential for environmental damage) (FEAM, 2018). 


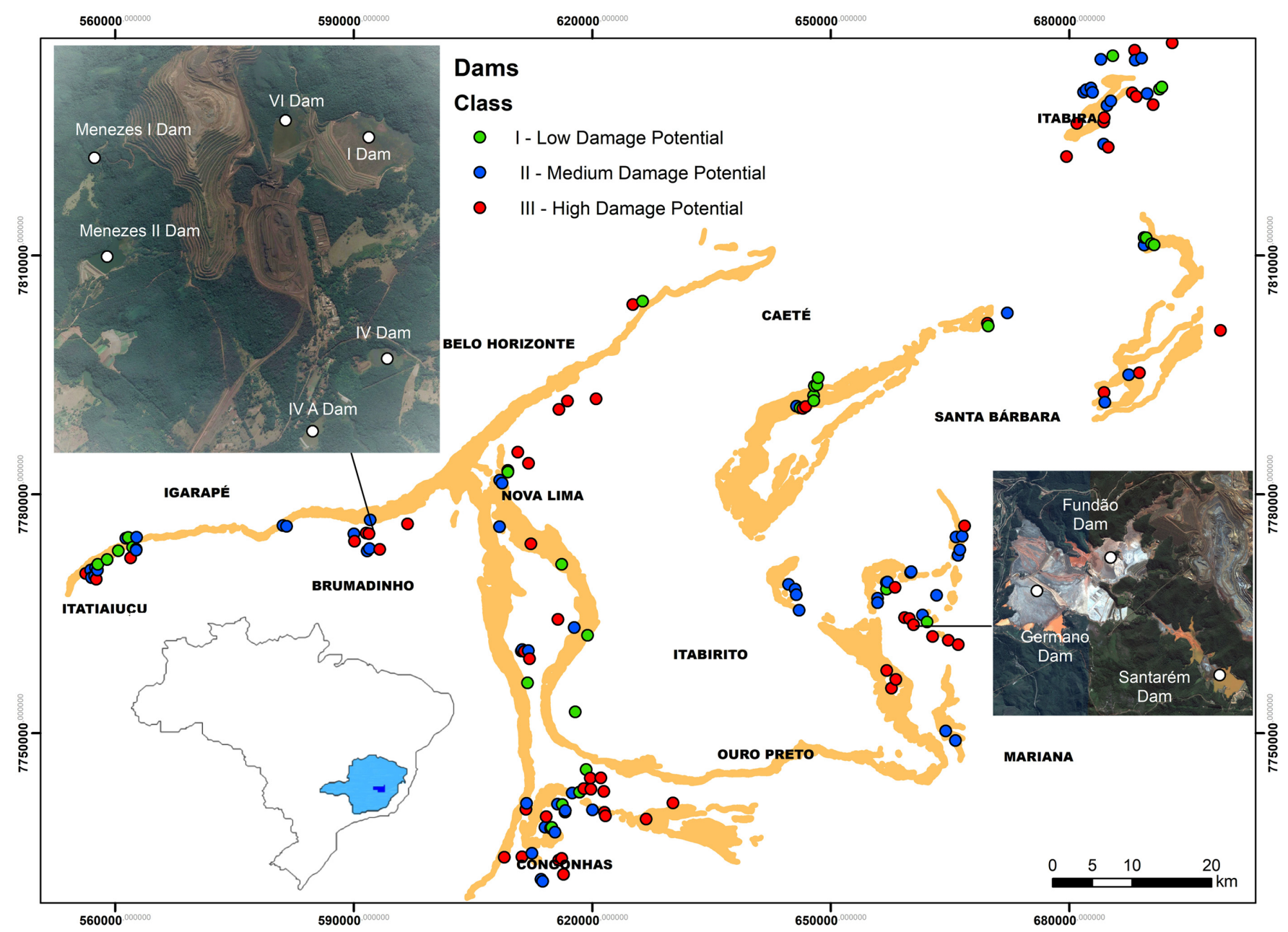

Figure 2. Location and classification of some of the mining tailings dams in the Quadrilátero Ferrifero. Prepared with data from FEAM (2018).

\section{Human Losses}

\section{Fundão Tailing Dam}

The municipality of Mariana, and specifically the sub-district of Bento Rodrigues, was one of the areas most affected by the rupture that caused the death of 19 people, among mine workers and community residents. The mud discharged destroyed all infrastructures, leading to the withdrawal of all residents, who will never be able to return to their place of origin, now known as "the old Bento". Silva et al. (2018) highlitght the emotional consequences of losses to communities, ranging from the emotional traumas resulting from the forced displacement of their residences to the loss of their pets and livestock (animals), which were killed. Being from Bento Rodrigues is part of community identity and this was permanently affected (Silva et al., 2016). Throughout generations there were shared significant experiences and traditions, reminiscent of the lifestyles of different settlers that inhabited the region. They are "ways of creating, doing and living" that must be acknowledged as heritage and safeguarded as part of the identity, action and memory of Brazilian mining traditional livelihoods in general and from Minas Gerais society in particular (Silva et al., 2016).

\section{Córrego do Feijão Tailing Dam}

The Córrego do Feijão tailing dam in Brumadinho, which stands out for the magnitude of the number of victims: 257 deaths and 13 missing - according to official data from Civil Policy of Minas Gerais state, 28 November 2019 (PCMG, 2019). Soon after the rupture, the assistance came from the affected people, and afterwards by Vale employees, municipal leaderships, fire brigade of the State of Minas Gerais and Civil Defense.

In the disaster area, three large support centers were set up: 1) the Knowledge Station, a Vale structure where the population-related support and care actions were concentrated, such as the official list of dead and missing persons, registration of relatives, etc; 2) the Asa College, where the operational command of public entities such as the civil and military police, the fire brigade, the state civil defense and the governmental environmental agencies were established; 3) the Catholic Church in Córrego do Feijão, where the fire brigade was set up, in charge of locating the bodies, and the police in charge of identifying the victims' bodies (CENACID, 2019).

The Vale mining company initiated a set of emergency and humanitarian activities providing assistance, including medical and psychological support with specialized staff, insecticide fumigation to prevent the proliferation of mosquito vectors carrying diseases such as dengue 
and yellow fever. It also provided approximately 14 million liters of water for human and animal consumption and irrigation in agricultural lands (Vale, 2019).

Several communities were isolated by the tailings mud with restricted access to health services. This situation may have exacerbated existing diseases or caused mental illness (depression and anxiety), hypertensive crises, cutaneous and respiratory diseases (Fiocruz, 2019). The National Human Rights Council (CNDH), at the request of the Movement of Dam Affected People (MAB), carried out an on-site reconnaissance mission on January 30, 2019. The results of this mission highlighted several recommendations, as following: the correct identification of Vale employees as such in the service stations; the company's performance in order to communicate and dialogue with the community using accessible language; the correction of the information release in the certificates of death as resulting from the rupture of the tailing dam of Córrego do Feijão Mine, to instead report it to Vale's company, and not a "municipal event" (CNDH, 2019).

\section{Loss of Heritage}

\section{Fundão Tailing Dam}

The rupture of the Fundão tailing dam was the largest in the world in terms of both environmental damage and loss of cultural heritage, releasing 43,000,000 $\mathrm{m}^{3}$, across $663 \mathrm{~km}$ in the Rio Doce river basin until reaching the Atlantic Ocean.

Numerous 17th and 18th century colonial monuments representing the Gold Cycle in Brazil were destroyed, including the São Bento Chapel (built in mid-1718) and dry stone walls. The mud-wrecked landscape of Bento Rodrigues was praised in the descriptions of several naturalist travelers who traveled the region at different times between 1816 and 1841: Johann Baptist Emanuel Pohl (Austrian); George Gardner (English); Carl Friedrich Philipp von Martius (German); Auguste de Saint-Hilaire (French).

According to the Public Ministry of the State of Minas Gerais $\left(\mathrm{MPMG}^{1}\right)$, fifteen natural underground cavities were affected by the mud from the Fundão tailing dam breach, five of which are completely underground. The loss of these assets led the MPMG to raise a Public Civil Action in 2016, against Samarco, Vale and BHP Billiton. In the argument of the claim the MPMG points out that damage to speleological heritage may imply deprivation of enjoyment and access to protected assets, loss of the possibility of reaching scientific knowledge. The prosecutors responsible for the action point out that most of the area affected had not yet been monitored, which probably means that science will not be able to bring this knowledge to the world.

As the rupture of the tailing dam reached several tributaries of the Doce River Basin, it is inevitably linked to a significant loss of the heritage associated with geodiversity. Mendes and Felippe (2016) highlight the significant modification of the lower valley morphology, with an area of $2.82 \mathrm{~km}^{2}$ being covered by the technogenic deposits, due to the enormous amount of sterile material deposited. The river channels were silted, and this will give rise to a new morphology for these channels.

\section{Córrego do Feijão Tailing Dam}

The official year of the foundation of the municipality of Brumadinho dates back to 1938 . However, the occupation history of the region is much older, as for example, the establishment of settlements in the middle course of the Paraopeba River began in the late 17th and early 18th centuries. These settlements developed during the Gold Rush that led to several expeditions in search of mineral riches. The village of Córrego do Feijão began to be occupied in the 1940s and became a district of the municipality of Brumadinho in 2004. In the context of the Iron Cycle, mining in Córrego do Feijão began in 1923 by Ferteco, whose shareholding control passed to Vale in 2001 (Gomes, 2009).

Tailings from the rupture of the Córrego do Feijão Dam buried Ribeirão Ferro-Carvão, a tributary of the right bank of the Paraopeba River. According to the Forest Institute, the geographical position of this sub-basin in the region close to the Metropolitan Region of Belo Horizonte (headquarters of Minas Gerais state), gives it an important role for both urban and industrial wood supply (IEF, 2013).

Feijão tributaries fluvial dynamics were significantly affected mainly due to water velocity, tracing, sediment load and erosive and depositional capacity. In the Paraopeba River the turbidity spot has advanced tens of kilometers, producing impacts such as lower oxygenation, reduction of light penetration and modification of drainage morphological conditions (CENACID, 2019).

The mine is located in the South Environmental Protection Area of the Metropolitan Region of Belo Horizonte (APA Sul RMBH) and in the buffer zone of the Serra do Rola Moça State Park. This area is classified as priority area for biodiversity conservation in Minas Gerais, being included into the transition zone between Atlantic Forest and Cerrado biomes (IEF, 2014). Tobias Jr. et al. (2015) show that in the area of influence of the Córrego do Feijão there are sites of historical and archaeological heritage. At least eight archaeological sites identified by the National Historical and Artistic Heritage Institute (IPHAN) were on the mud route: Samambaia 1 and 2, Córrego do Feijão aqueduct, Berro 2, Fazenda Velha 1 and 2 and Fazenda Recanto 1 and 2. There are still other sites that may have been compromised along the Paraopeba River (Amâncio, 2019).

\section{Discussion}

\section{Geoethics in the Context of Tailings Dam Break}

Although geoethics has its most developed corpus in relation to the role of geoscientists for better scientific and professional practice (Bohle and Di Capua, 2019), it is important that geoethical premises are also used by companies that have responsibilities in managing geo-resources. This may be a desirable future path for the geoethics approaches.

\footnotetext{
${ }^{1}$ The concept and general objectives of the Public Ministry in Brazil (in Portuguese Ministério Publico de Minas Gerais) are established by the Constitution of the Brazilian Republic, 1988. In general, the Brazilian Public Ministry aims to contribute to provide balance and justice to the jurisdictional function in that country. The Public Ministry functions are to defend and enforce the law, democracy and human rights, such as environmental law. It is important to highlight that the Brazilian Public Ministry has legal, political and administrative autonomy. In this way, he can act in Brazil as a true "lawyer for society", especially in conflicts or discussions about diffuse or collective rights.
} 
In this sense, the Cape Town Statement on Geoethics, approved by the International Association for Promoting Geoethics (IAPG, 2016), aims to capture the attention of geoscientists and organizations, and to stimulate them to improve their shared policies, guidelines, strategies and tools to ensure that they consciously embrace (geo) ethical professional conduct in their work. According to the Statement, geoscientists are tasked with engaging with society. In the coming years, especially when addressing matters like energy supply, use of georesources, land management, pollution abatement, mitigation of geohazards climate change adaptation and mitigation, ethical and social issues will be central in scientific discussion and in public debate.

In Brazil, the increasing demands for mineral commodities have not yet been accompanied by comprehensive ethical approaches that have led to a high risk potential for communities living around mining, especially in relation to the disruption of tailing dams. Tailing dam ruptures can radically change people's lives and affect the environmental balance. Companies that operate locally and internationally cannot adopt ethical practice only when their operations are located in developed countries, but also when they are in developing or countries with emerging economies

In the case of the Fundão tailing dam rupture, the community of Bento Rodrigues was severely affected with a huge loss for future generations, who will not have access to the heritage associated with the history of mining identity of the old settlement of Bento Rodrigues. The loss of the speleological patrimony with the breaking of the Fundão tailing dam is also irreparable. This caused the suppression of at least fifteen cavities impacted by the mud, implying the deprivation of access to the geoheritage trapped there with the inherent loss of scientific knowledge associated with it.

In the case of Córrego do Feijão, the loss or compromise of historical and archaeological heritage sites were reported by IPHAN to the Folha de São Paulo newspaper, highlighting the ones that where in the mud route. Mining companies, in addition to safeguarding human and cultural values should also be ethically concerned with mapping and protecting all heritage found in their area of influence, considering different scenarios for tailing dam disruptions under their responsibility.

More serious than property losses are the loss of human life, 19 in the case of the Fundão breach and 257 in the case of the Brumadinho tailing dam rupture. In the latter case, the seepage sludge hit domestic and livestock animals, birds and dogs - leading, in some cases, to the need to kill these animals (we could not find estimates for the number of animals that were shot). These animals had no salvage conditions and were dying.

In this regard, assumptions that underlie the principles and main concerns of geoethics (Peppoloni and Di Capua, 2016) could have been applied by mining companies. The mining companies, particularly failed the concern with the prevention and remediation of potential hazards as well as an adequate and accessible communication to communities.

Satellite images of the QF indicate the magnitude of tailings dams, which are amongst the largest man-made structures in this region. Safety measures to prevent tailings dam failures, both to protect life, property and natural resources, are essential needs in iron mining operations especially for the considerable volume of material mobilized.

Fundão and Córrego do Feijão ruptures occurred in tailing dams built by the upstream embankment system - the cheapest option of all.
In this sense, from the point of view of environmental ethics (Larrère and Larrère, 1997; Varandas, 2009) (which does not admit the pretentious conception that nature is only associated to means and business objectives) mining companies' responsibility is aggravated due to a number of reasons. The construction and maintenance of tailing dams by the upstream embankment method is, among other available techniques, the one that has the least costs for the entrepreneur. However, at the same time, it is the one that entails more risks of disruption and, consequently, of environmental and social damage, due to phenomena such as piping, liquefaction and seismic occurrences. Therefore, the adoption and maintenance of this type of technology may indicate that mining companies do not assumed the fundamental ethical duties of prudence and intergenerational solidarity (Ruchkys et al., 2019).

In the case of Córrego do Feijão, Ruchkys et al. (2019) based on news published in two Brazilian newspapers (State of Minas and Folha de São Paulo) indicate that: i) the company had been informed, before the breakup, about irregularities in deep horizontal drains into the tailing dam and discrepant data from the piezometers used for monitoring, and have not taken action on this; ii) and Brumadinho Emergency Plan provided, in the event of a breach, that the tailings could reach the restaurant and administrative area of the mining company - about two kilometers from the tailing dam. The safety of employees was not considered (Brasil, 2019). In making the simulation and finding the risk the company should have made new constructions to house the cafeteria and their own administrative area.

Information and communication are some of the fundamental aspects of geoethics, especially in risky activities such as mining. Both communication and information should be guiding axes of humanization processes in the event of disasters and therefore included in the quality of management of mining activities. In the case of Fundão's disruption, some of the workers witnessed the collapse of the tailing dam and immediately sought higher places to avoid being hit by the mud. There was no siren sounded or any other means of communication to alert workers and residents of the Bento Rodrigues community. Some employees warned colleagues via radio, and one of the residents who worked at the mine grabbed her motorcycle and rushed to alert the community, which, without any guidance and on its own, proceeded to escape (Salinas, 2016). In the Brumadinho disruption, the siren system did not work, and although some officials and members of the surrounding community had been trained, many were unaware of the risk they were taking. Part of the escape route provided for in the mining tailing dam's Emergency Plan was taken by the mud. Following the breaking of the Brumadinho tailing dam the public Ministry of Minas Gerais (MPMG) demanded from mining companies stability reports of all tailing dams built by this method in the Quadrilátero Ferrifero (CIAEA, 2020). There is not yet harmonization of interests of all societal groups that live in the Quadrilátero Ferrífero with respect to the use of geodiversity resources (MPMG, 2020). The strong dependence of municipalities on mining companies, instead of increasing their responsibility, might lead them to overlook actions in relation to security and damage to assets. Estimates of possible changes resulting from major works (in the case of expansion of tailings dams) considering any potential, even hypothetical, hazards - were not adequately addressed neither by Vale nor by Samarco in the Brumadinho and Fundão tailing dam breaches, respectively. 


\section{Final Considerations}

The exploration of geological resources in the Quadrilatero Ferrifero dates back to the 17 th century. Nowadays, the management of this area is particularly challenging. A major issue is to reconcile intensification of iron ore exploitation as the main mineral commodity from the 1970s onwards with the conservation of nature in the region (water sources and the region rich biodiversity) along with socio economic heritage (sites of historical, archaeological, geological, speleological). The impacts of open-cast iron mining are not restricted to the pit, but to the development of the whole extraction process, including the heavy traffic of heavy machinery, the implementation of the industrial plant and the disposal of tailings produced during the mining and processing of iron ore.

The damages caused by the tillage dam breaks in Mariana and Brumadinho are immeasurable, starting from the assumption that the valuation of the nature and way of life of the community will never return to the state before due to the very serious environmental degradation caused by the mud. In addition, the mining industry in the Quadrilátero Ferrífero, which lasts for centuries, modifies the environmental balance and the physiognomy of landscapes, even if, from a positive point of view, it is the guiding thread of the identity and historical memory of the communities living in this geosystem.

Mining, as practiced in the Quadrilátero Ferrífero, creates the illusion of an activity exclusively of aggregating value to the population. Therefore, the concern with its associated risks and impacts is not, in a way, evident and important in the eyes of many people. The recent disruptions of the Fundão (2015) and Córrego do Feijão (2019) tillage dams are changing this perspective, educating residents of the QF to the perception that the neighborhood with mining does not only bring benefits. The risks and negative environmental impacts of the activity in question are quite significant, contributing to the degradation of the landscape and to the decrease of the quality of the water sources (Alvarenga, 2015; Ruchkys et al., 2019).

However, the ban on the continuation of mining activities is obviously inadequate. Mining is the main economic activity of the whole QF. There is a pressing need to find an adequate solution, based on geoethical principles, including considering to closed down the mines and proceed to land remediation when they are exhausted. This is a geoethical dilemma that needs to be acknowledged in all the mining areas and, especially, in the Quadrilátero Ferrífero. Evidence has been pointing out that we need to learn from two of the major anthropogenic catastrophes associated with mineral extraction: the rupture of the tillage dams of Fundão and Córrego do Feijão.

Geoethical lessons that should be learned by the mining companies involved in the two recent tailing dam breaches in the Quadrilátero Ferrífero are: (i) to have a long term plan to develop waste management using no tailings ; ii) to care for the efficient instrumentation of the dam monitoring system; (iii) to use safer, modern and technology driven disposal methods such as disposal in depleted pits, controlled piles or even in underground mine gallery; iv) to investment in waste reuse technologies as inputs for civil construction in the production of floors, bricks, blocks and tiles - the Federal University of Minas Gerais (UFMG), Ouro Preto (UFOP) and Lavras (UFLA) have already developed prototypes with this goal (Gomes, 2017; Machado, 2018; Fontes et al., 2019); v) to improve mass recovery in the industrial plants vi) detailed mapping of the entire natural and cultural heritage surrounding dams that could be affected in the event of a breach; vii) to map the location of surrounding communities; viii) to develop an effective communication programme that clearly addresses the risks to which communities are subjected to living with large mining enterprises; ix) to promote public engagement with communities in case of expansion of mining activities; $\mathrm{x}$ ) to share and made available studies on tailing dam rupture indicating possible routes of flooding areas.

The UN 2030 agenda for sustainable development advocates effective social participation and social justice, not just the state and the entrepreneur in decisions concerning industrial activities. Specifically, for mining, the Agenda 2030 document is based on previous sector sustainability documents (ICMM, 2012).

Added to this is the responsibility to future generations. Vale was born in Minas Gerais and has been operating in the Quadrilátero Ferrífero since 1942 with the exploration of large deposits of iron ore that promoted significant changes in the landscape and created a strong dependency in the municipalities where its facilities are located and in neighboring municipalities. These two associated factors should reflect on the company in geoethical actions of concern and responsibility towards future generations.

After almost 80 years of exploration, from a geoethical point of view, Vale should adopt in the Quadrilátero Ferrífero a path of gratitude, helping to strengthen this mining identity by bringing alternatives to society through geotourism and the expressive appreciation of geomine heritage (Ruchkys et al., 2019). This is valuing the past by focusing on the future. CEFEM for $2 \%$ iron ore on the company's net sales is a negligible value close to the impacts generated by the activity and the company's high profit (Ruchkys et al., 2019).

One of the biggest challenges for geoethics will be to find a better way of justly distributing geodiversity resources in a growing demand for mineral inputs. This issue is indispensable for geoethics to be incorporated and debated not only in the context of geoscience training courses and geoscientists, but also by companies and activities that have geodiversity as their main source of income. These companies need to be concerned beyond complying with legal precepts and effectively incorporate comprehensive geo-ethical values related to the dignity of the communities affected by their activities, respect for environmental and cultural heritage and the need to ensure alternative uses for territories in order not to compromise the needs of future generations.

\section{Acknowledgements}

We are gratefull to FAPEMIG for the financing support to the Project APQ-02956-16 and to CNPQ for the PQ grants to URA and SCR.

\section{References}

Alvarenga, L.J., 2015, A mineração à prova do paradigma da produção ecologicamente sustentável: entre cartografias utópicas, teatralidades e a vivificação do projeto constitucional de afirmação da justiça socioambiental. Revista Internacional de Direito Ambiental, No. 12, pp. 191-218. 
Araujo, E.R., Olivieri, R.D., and Fernandes, F.R.C., 2014, Atividade mineradora gera riqueza e impactos negativos nas comunidades e no meio ambiente. In: Fernandes, F.R.C.; Alamino, R.C.J.; Araujo, E. (Eds.). Recursos minerais e comunidade: impactos humanos, socioambientais e econômicos. Rio de Janeiro, Cetem, pp. 1-12.

Amâncio, T., 2019, Lama da Vale pode ter destruído sítios arqueológicos em Brumadinho, Jornal Folha de São Paulo. https:/www1.folha.uol. com.br/cotidiano/2019/02/lama-da-vale-pode-ter-destruido-sitiosarqueologicos-em-brumadinho.shtml. [accessed 14th February 2019].

Arvanitidis N., Boon J., Nurmi P. and Di Capua G., 2017, White paper on responsibile mining. IAPG - International Association for Promoting Geoethics. https://www.geoethics.org/wp-responsible-mining. [accessed 20th February 2019].

Bohle, M., and Di Capua, G., 2019, Setting the scene. In: Bohle, M., Ed., Exploring geoethics-ethical implications, societal contexts, and professional obligations of the geosciences. Cham, Switzerland, Springer international publishing, pp.1-24.

Brasil, 1988, Constitution of the Federative Republic of Brazil, Biblioteca digital da Câmara dos Deputados, Centro de Documentação e Informação, Coordenação de Biblioteca. http:/www.stf.jus.br/repositorio/ cms/portalStfInternacional/portalStfSobreCorte_en_us/anexo/constituicao_ingles_3ed2010.pdf. [accessed 12th July 2019].

Brasil, 2019, Relatório de Análise de Acidente de Trabalho: rompimento da barragem B1 da Vale S.A. em Brumadinho/MG em 25/01/2019, Ministério da Economia, Secretaria Especial de Previdência e Trabalho, Secretaria do Trabalho / Subsecretaria de Inspeção do Trabalho, Superintendência Regional do Trabalho em Minas Gerais, SEGUR - Seção de Segurança e Saúde do Trabalhador. file://C:/Users/ljalv/Desktop/ Relatorio Analise Acidentes SAMARCO-BRUMADINHO.pdf [accessed 31 March 2020].

Carmo, F.F., and Kamino, L.H.Y., 2015, Geossistemas Ferruginosos do Brasil: áreas prioritárias para conservação da diversidade geológica e biológica, patrimônio cultural e serviços ambientais. Belo Horizonte: $3 \mathrm{i}$ Editora, $552 \mathrm{p}$.

Cardozo, A.C., Pimenta, M.M., and Zingano, A., 2016, Métodos construtivos de barragens de rejeitos de mineração - uma revisão. Holos, v. 8, pp. 77-85.

CIAEA, 2020, Comitê Independente de Assessoramento Extraordinário de Apuração http://www.vale.com/PT/investors/Documents/2020_02_20_ Relatorio_CIAEA.pdf [accessed 27th February 2020].

CENACID - Centro de Apoio Científico em Desastres, 2019, Relatório missão CENACID emergencial para apoio a resposta ao desastre relacionado ao rompimento da barragem de rejeitos da Mina Córrego do Feijão, pertencente a Cia. Vale do Rio Doce, no município de BrumadinhoMG.http://www.cenacid.ufpr.br/portal/wp-content/uploads/2019/02/ Relat\%C3\%B3rio_CENACID-BRU_finalA.pdf. [accessed 14th February 2019].

CNDH - Conselho Nacional de Direitos Humanos, 2019, Relatório da missão emergencial a brumadinho/MG após rompimento da barragem da Vale S/A. https://www.mdh.gov.br/todas-as-noticias/2019/fevereiro/missaoemergencial-do-cndh-apresenta-relatorio-sobre-rompimento-de-barragem-da-vale/RelatrioMissoemergencialaBrumadinho.pdf. [accessed 15th February 2019].

Derani, C., 1998, Meio ambiente ecologicamente equilibrado: direito fundamental e princípio da atividade econômica. Advocacia pública \& sociedade, No. 3, pp. 91-101.

Derani, C., 2008, Direito ambiental econômico. São Paulo, Ed. Saraiva, $290 p$.

DNPM - Departamento Nacional de Produção Mineral (2015a). Informe mineral 1/2015 (janeiro a junho). Brasília, DNPM, 23 pp.

DNPM - Departamento Nacional de Produção Mineral (2015b) Informe Mineral 2/2015 (julho a dezembro). Brasília, DNPM, 22 pp.

DNPM - Departamento Nacional de Produção Mineral (2016) Informe Mineral 1/2016 (janeiro a junho). Brasília, DNPM, 15 pp.
Druguet, E., Passhier, C.W., Pennachioni, G., and Carreras, J. 2013, Geoethical education: a critical issue for geoconservation. Episodes, v. 36, http://diarium.usal.es/mdp/files/2012/06/March-2013.pdf\#page=11. [accessed 18th February 2019].

Drummond, J.A., and Barros-Platiau, A.F., 2006, Brazilian Environmental Laws and Policies, 1934-2002: A Critical Overview. Law and Policy, Vol. 28, pp. 83-108, ISSN 0265-8240.

EPA, 1994, Environmental Protection Act. Queensland. https://www.legislation.qld.gov.au/view/pdf/inforce/current/act-1994-062 [accessed 27 February 2020].

FEAM, 2018, Gestão de barragens, relatórios técnicos, lista de barragens de 2018. http://www.feam.br/monitoramento/gestao-de-barragens. [accessed 12th February 2019].

Fiocruz, 2019, Avaliação dos impactos sobre a saúde do desastre da mineração da Vale (Brumadinho, MG). http://www.epsjv.fiocruz.br/sites/ default/files/files/relat\%C3\%B3rio Brumadinho impacto sa $\% \mathrm{C} 3 \%$ BAde_01_fev_b.pdf. [accessed 19th February 2019].

Fontes, J.M.F., Andrade, L.C.R., Segadães, A.M., and Peixoto, R.A.F. 2019, Assessment of the use potential of iron ore tailings in the manufacture of ceramic tiles: From tailings-dams to "brown porcelain". Construction and Building Materials, No. 19, pp. 111-121.

Gomes, A.C.F., 2017, Estudo de aproveitamento de rejeito de mineração, Programa de Pós-Graduação em Engenharia Metalúrgica, Materiais e de Minas, Dissertação de Mestrado, Belo Horizonte, 87 p.

Gomes, R.C., 2009, Caracterização tecnológica e sistemas de disposição de resíduos de mineração, Núcleo de Geotecnia da Escola de Minas, Universidade Federal de Ouro Preto, Dissertação de Mestrado, Ouro Preto, 220p.

Gutberlet, J., 1996, Produção industrial e política ambiental: experiências de São Paulo e Minas Gerais. São Paulo, Fundação Konrad-AdenauerStiftung, 153p.

Hochstetler, K., 1997, The evolution of the Brazilian environmental movement and its political role. In: Chalmers, D. et al. (Eds.). The new politics of inequality in Latin America: rethinking participation and representation. Oxford/New York, Oxford University Press, pp. 192-216.

Hochstetler, K., 2002, Brazil. In: Weidner, H.; Jänicke, M. (Eds.). Capacity building in national environmental policy: a comparative study of 17 countries. Berlin, Springer, pp. 69-95.

IAPG, 2016, Cape Town Statement on Geoethics. http://www.geoethics.org/ ctsg [accessed 18th July 2019].

ICMM, 2012, Human rights in the mining and metals industry: Integrating human rights due diligence into corporate risk management processes. http:// www.icmm.com/document/3308. [accessed 18th July 2019].

IEF, 2013, Parecer único de compensação ambiental gca/diap nº 043/2013 Vale S.A. - mina do Córrego do Feijão. http://www.reunioes.semad.mg. gov.br/down.asp?x_caminho=reunioes/sistema/arquivos/material $/ \& x_{-}$ nome=Item_5.15_-_PU_GCA_043.13_Vale_Mina_do_C\%BA_do_Feij\%E3o.pdf. [accessed 11 th February 2019].

IEF, 2014, Parecer único de compensação ambiental gca/diap nº081/2014 Vale S.A. - mina da Jangada. http://www.reunioes.semad.mg.gov.br/down. asp?x_caminho=reunioes/sistema/arquivos/material $/ \& x \_n o m e=I t e m \_6.1$ Vale SA Mina Jangada.pdf. [accessed 11 th February 2019].

Larrère, C., and Larrère, R., 1997, Du bon usage de la nature: pour une philosophie de l'environnement. Paris, Éditions Flammarion, 356 pp.

Leite, J.R.M., and Ayala, P.A., 2020, Dano ambiental. Rio de Janeiro: Forense. $448 \mathrm{p}$.

Lozano, F., 2006, Seleção de locais para barragens de rejeitos usando o método de análise hierárquica, Dissertação de Mestrado, Universidade de São Paulo, São Paulo, 115 p.

Machado, M.de S.M.M., 2018, Blocos para construção civil feitos com rejeitos depositados na Barragem de Candonga, Programa de Pós-Graduação em Engenharia de Materiais, Dissertação de Mestrado, UFOP, Ouro Preto, $98 \mathrm{p}$

Mendes, L.C., and Felippe, M.F., 2016, A geomorfologia do tecnógeno e 
suas relações com o rompimento da Barragem Fundão (Mariana, Minas Gerais). Revista de Geografia - PPGEO - UFJF, v. 6, pp. 353-362.

MPMG, 2020, Procedimento Investigação Criminal 0090.19000013-4 e Inquérito Policial PCMG 7977979 file://C:/Users/Sonia/Documents/ artigos2019/geoetica/bibliografia/Den_ncia\%20VALE-TUV\%20SUD\%20$\% 20$ homic_dio $\% 20 \mathrm{e} \% 20 \mathrm{crime} \% 20 \mathrm{ambiental} \% 20$ site_pdf [accessed 27 February 2020].

PCMG, 2019. https://www.policiacivil.mg.gov.br/noticia/exibir?id=2343135 [accessed 26 February 2020].

Peppoloni, S., and Di Capua, G., 2016, Geoethics: ethical, social, and cultural values in geosciences research, practice, and education. In: Wessel, G.R., and Greenberg, J.K. (Eds.). Geoscience for the public good and global development: toward a sustainable future. Geological Society of America, Special Paper, pp. 17-21.

Peppoloni, S. and Di Capua, G., 2012, Geoethics and geological culture: awareness, responsibility and challenges. Annals of Geophysics, No. 55, p. 335-34. doi: https://doi.org/10.4401/ag-6099.

Peppoloni, S., 2012, Social aspects of the Earth sciences, interview with Prof. Franco Ferrarotti. Annals of Geophysics, No.55, p.347-348. doi: 10.4401/ag-5632.

Pinheiro, G.M. dos S., 2018, Ferruginous geosystems and the current situation of iron in brazil: economic growth or environmental regression? In: Acevedo, R.D., Frías, J.M. (Eds.), Geoethics in Latin America. Springer International Publishing AG, part of Springer Nature, The Latin American studies book series, p. 39-58. doi: org/10.1007/978-3319-75373-7_5.

Ribeiro Filho, E., Moreschi, J.B., and Macedo, A.B., 1988, Minerals and mining in the brazilian economy. Episodes, v. 11, No.3. http://www.episodes.org/journal/view.html? volume $=11$ \&number $=3 \&$ spage $=215 \& \mathrm{vmd}=$ Full. [accessed 13th August 2019].

Ruchkys, U.A., 2015, Sítios geológicos e propostas brasileiras de geoparques em geossistemas ferruginosos. In: Carmo, F.F., Kamino, L.H.Y. (Org.), Geossistemas ferruginosos do Brasil: áreas prioritárias para conservação da diversidade geológica e biológica, patrimônio cultural e serviços ambientais. Belo Horizonte, 3i editora, pp. 169-193.

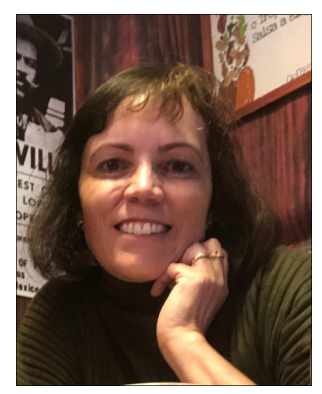

Úrsula de Azevedo Ruchkys is a geologist graduate and Ph.D in Geology at Federal University of Minas Gerais. (UFMG) (Brazil). Her Ph.D studies in the Quadrilátero Ferrifero (Brazil) led to the proposal for measures to geological heritage conservation of this important Precambrian terrain. Since 2009 she is a Professor at Cartography Department and Professor in the Master and Doctorate Program in Geography and in Environmental Systems Modeling Analysis, Institute of Geosciences, UFMG. She has a Scholarship by National Council for Scientific and Technological Development - CNPq (Research Productivity - level 2). Her current interests include: geoethics; geodiversity; geoheritage; geotourism; mining history; ferruginous geosystems and; analysis and modeling of environmental systems using GIS. She has published extensively on these topics.
Ruchkys, U. de A., Castro, P. de T.A., and Miranda, M.P.S., 2019, Mineração em geossistemas ferruginosos e questões de geoética: o caso do rompimento da barragem de Córrego do Feijão, Minas Gerais - Brasil. Confins, No.40. doi: 10.4000/confins. 19973 .

Salinas, N., 2016, Caso Samarco: implicações jurídicas, econômicas e sociais do maior desastre ambiental do Brasil. In: Porto, A., Falcão, J., Alcantara, P. (Org.), Depois da lama: Mariana e as consequências de um desastre construído. Belo Horizonte, Letramento, pp. 197-234.

Santos, P.F., and Borges, L.A.C., 2019, Sustentabilidade do licenciamento ambiental minerário em Minas Gerais: caso aplicado. Engenharia Sanitária e Ambiental, vol. 24, pp. 463-472. doi: 10.1590/S1413-41522019175858.

Silva, G., Boava, D., and Macedo, F., 2016, Refugiados de Bento Rodrigues: estudo fenomenológico sobre o desastre de Mariana, MG. In: IV Congresso Brasileiro de Estudos Organizacionais - Porto Alegre, RS, Brasil, 19 a 21 de Outubro de 2016. https://anaiscbeo.emnuvens.com.br/cbeo/article/download/205/197. [accessed 11th August 2019].

Tobias Jr., R., Nascimento, E.L.M., and Rodrigues, I.M.M., 2015, Contexto arqueológico e longa duração nas serras do Paraopeba, Negra e do Itabira, MG. In: Carmo, F. F., Kamino, L. H. Y. (Org.), Geossistemas ferruginosos do Brasil: áreas prioritárias para conservação da diversidade geológica e biológica, patrimônio cultural e serviços ambientais. Belo Horizonte, 3i editora, pp. 429-463.

USGS, 2014, Mineral commodity sumaries. https://minerals.usgs.gov/minerals/pubs/mcs/2014/mcs2014.pdf. [accessed 1st March 2019].

Vale, 2019, Atualização sobre Brumadinho. http://www.vale.com/PT/investors/information-market/presentations-webcast/PresentationsWebCastDocs/ Atualiza\%C3\%A7\%C3\%B5es\%20Brumadinho_20190228_p\%20v12.pdf. [accessed 1st March 2019].

Varandas, M.J., 2009, Ambiente: uma questão de Ética. Lisboa, Esfera do Caos Editores, 112 pp.

Velho, J., 2006, Os recursos minerais: uma visão geo-histórica. Palimage editores, Braga, 478p.

Wise Uranium Project, 2019. http://www.wise-uranium.org/mdaf.html.

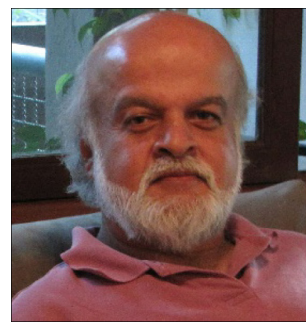

Paulo de Tarso Amorim Castro is full professor at the Federal University of Ouro Preto where he works in undergraduate teaching in Geological Engineering and in the Graduate Program in Crustal Evolution and Natural Resources and also at Graduate Program in Modeling Earth and Environmental Sciences at the State University of Feira Santana, Bahia (Brazil). He is a geologist from Federal University of Minas Gerais, He did his master's degree in Crustal Evolution and Natural Resources at School of Mines, Federal University of Ouro Preto and his doctorate in Geology at University of Brasília, all of them in Brazil. Paulo research projects is focused on geology and environment, acting mainly on the following topics: Quadrilátero Ferrifero region, mining impacts on alluvial systems, geoconservation and geoethics. 


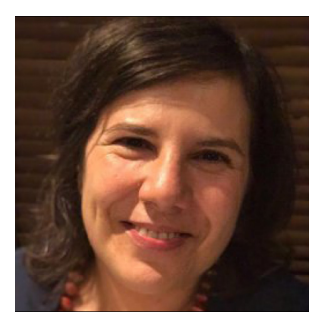

Sónia Maria Carvalho Ribeiro is a Professor at Cartography Department, Institute of Geosciences, Federal University of Minas Gerais (UFMG). Sonia is vice-coordinator of both the post graduate program on Environmental Modeling and Centro Sensoriamento Remoto (CSR). She worked as post doc at CSR-UFMG (Scholarship by CNPqYoung Talent), University of Évora, Portugal (Portuguese Science Foundation, FCT), University of Lisbon, Portugal and University of East Anglia, UK (Horizon, European Union). Sónia's work develop at the science policy interface focusing on the effects of land cover/use dynamics on the provision of multiple Ecosystem Services (ES) at multiples scales of governance. Research topics range from sustainable use of wild species, Non Timber Forest Products (NTFP), forest livelihoods, sociobiodiversity, forest restoration to future socio-economic scenarios. She holds graduation in Forestry Science by University of Trás-os-Montes e Alto Douro (UTAD), Portugal; master in Rural Development by UTAD and Santiago Compostela University, Spain; PhD at the School of Environmental Sciences, University of East Anglia, Norwich, UK.

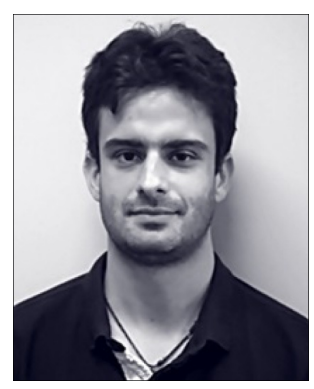

Luciano José Alvarenga is a professor and associate researcher at the Brazilian Society for Scientific Progress (SBPC). He develops interdisciplinary investigations and critical reflections based on dialogues between law and other sciences. His research focuses on the interrelationship between law and a variety of other subject areas, such as environmental justice, conservation of the Cerrado biome (Brazilian Savanna), geoheritage, landscape, geoconservation and geoethics. Professor Alvarenga graduated from the Federal University of Minas Gerais (Brazil) with a law degree. He holds a Specialist's Degree in Environment, Education and Sustainability from the University of Evora (Portugal) and a Ph.D. in Natural Sciences from the Federal University of Ouro Preto (Brazil). He is also a Ph.D. student in Legal Sciences at the University of Minho (Portugal), where he is part of the team of the Research Center for Justice and Governance (JusGov). Author of critical essays, books and articles, and active member of several research groups on environmental issues. 